THE COLLATERAL CONSEQUENCES OF GPS-LED SUPERVISION IN HOT SPOTS POLICING

\author{
Neil Wain \pm \\ Barak Ariel† \\ Justice Tankebe $\neq$
}

$\pm \quad$ Retired ACC (GMP), PhD Candidate, Institute of Criminology, University of Cambridge, Sidgwick Avenue Cambridge CB3 9DA UK; nw268@cam.ac.uk. Tel 07769931186.

$\dagger \quad$ Corresponding Author; PhD, Lecturer in Experimental Criminology, Institute of Criminology, University of Cambridge, Sidgwick Avenue Cambridge CB3 9DA UK, ba285@cam.ac.uk and Assistant Professor, Institute of Criminology, Faculty of Law, Hebrew University, Mount Scopus, Jerusalem 91905 Israel; barak.ariel@mail.huji.ac.il

$\ddagger \quad$ University Lecturer, Institute of Criminology, University of Cambridge, Sidgwick Avenue Cambridge, CB3 9DA UK; JT340@cam.ac.uk 
THE COLLATERAL CONSEQUENCES OF GPS-LED SUPERVISION IN HOT SPOTS POLICING

\section{BIOS}

BARAK ARIEL: Dr. Barak Ariel is a Lecturer in Experimental Criminology at the Institute of Criminology at Cambridge University and Lecturer at the Institute of Criminology, Faculty of Law, Hebrew University.

JUSTICE TANKEBE: Dr. Justice Tankebe is a University Lecturer in Criminology and a Fellow at St. Edmund's College at the University of Cambridge, United Kingdom.

NEIL WAIN: a PhD candidate in Criminology, working on issues related to hot spots and police accountability. Neil has had 30 years of experience in policing with the Greater Manchester Police. His interests focus on preventative policing and tracking police resources in crime hot spots. 


\title{
THE COLLATERAL CONSEQUENCES OF GPS-LED SUPERVISION IN HOT SPOTS POLICING
}

\begin{abstract}
Hot spots policing is popular, yet little is known about officer receptivity to the tactic and its impact on internal procedural justice, organizational commitment, and self-legitimacy. The nature of the tactic means that officers must relinquish their discretionary powers so that they can be directed to crime and disorder locations at specific times and for regimented durations. This loss of 'spatiotemporal autonomy' is exacerbated by technological tracking devices. We examined the receptivity of British officers to hot spots patrols, where the deployment was tracked with individual GPS trackers, compared to parallel patrols without hot spots policing or tracking. In contrast to the comparison group, officers in hot spots disliked the routinization of their shifts; regimented patrols were detrimental for internal procedural justice and organizational commitment. The ramifications of the introduction of GPS-enabled systems include certain tracking of officers and their compliance, such as a Taylorist time and motion study. While hot spots policing remains an effective tactic, questions about sustainability may be raised if officers' expectations, attitudes and receptivity are not managed.
\end{abstract}

KEYWORDS: tracking, GPS, hot spots, experiment, implementation, Taylorism 


\section{INTRODUCTION}

'Hot spot policing' - crudely described as a tactic of placing 'cops on the dots' - has been subjected to dozens of rigorous tests. A recent Campbell Collaboration systematic review showed that most tests of hot spot policing were associated with significant reductions in crime in treatment hot spots, compared to control conditions (Braga, Papachristos, \& Hureau, 2012; see also National Academy of Sciences, 2004). The list of hot spots experiments is continuously growing (e.g., Ariel \& Partridge, 2016; Ariel, Weinborn, \& Sherman, 2016; Ratcliffe et al., 2011; Rosenfeld, Deckard, \& Blackburn, 2014, Telep, Mitchell, \& Weisburd, 2012) and collectively reflects a 'strong body of evidence [which] suggests that taking a focused geographic approach to crime problems can increase the effectiveness of policing' (Skogan \& Frydl, 2004, p. 247). There is also evidence to suggest that in the aftermath of hot spot policing, crime is not spatially displaced to adjacent areas in the vicinity of the targeted hot spots (Bowers et al., 2011; Weisburd et al., 2004). Instead, there seems to be a 'diffusion of benefits of these social control mechanisms' to surrounding areas (Clarke \& Weisburd, 2004), or 'radiation' of the treatment effect (Ariel, 2014), not only 'around the corner' from the targeted hot spots (Weisburd et al., 2006), but also to larger geographic areas (Telep et al., 2014).

There have, however, been concerns about the potential unintended effects of hot spots policing. Two areas of interest are noteworthy in regard to police legitimacy. Firstly, there are concerns that increased and aggressive patrols in hot spots can have deleterious consequences for police external legitimacy and for collective efficacy (Rosenbaum, 2006; Kochel, 2011). Thus, according to Chermak, McGarrell, and Weiss (2001, p. 368),

If citizens think that such strategies are excessively intrusive, the benefit of some decrease in crime must be weighed against the alienation of the public. Moreover, if citizens react negatively to these efforts, the long-term result 
actually may be an increase in crime because citizens may be less willing to participate in the 'collective efficacy' of their neighborhood.

However, results from randomized controlled trials do not support these concerns. For example, Weisburd and his colleagues (2011) found that while aggressive order maintenance policing increased perceived physical disorder, it had no effect on fear of crime, police legitimacy, collective efficacy, or perceptions of crime or social disorder. In fact, residents appeared unaware of such policing practices on their blocks (see discussion in Ariel et al., 2016).

Secondly, similar concerns arise regarding research on the impact of hot spots policing on internal police legitimacy, or what can be referred to as police self-legitimacy and interpersonal relations. These concerns are raised primarily due to the very nature of hot spots policing: directed patrols, by definition, infer a substantial loss of discretion. The spatiotemporal precision that is required from hot spots policing patrols - exact locations and precise times - requires stripping officers of the ability to decide when and where to go, and with what dosage. It also requires meticulous and continuous timekeeping and accurate spatial tracking of these resources in order to assess the extent to which the patrol strategy has been delivered. The hot spots policing enterprise could potentially backfire and fail if these concerns are not addressed, let alone recognized. Yet research in this area is lacking.

In this study, we directly observed how aware officers are of being tracked in hot spots of crime and disorder in England and Wales and what consequences, if any, this might have on their self-legitimacy, internal procedural justice, organizational commitment, and the interpersonal trust of patrol or frontline officers. Our data come from a survey of officers participating in a hot spots experiment involving the use of a Global Positioning System (GPS) tracking system. GPS has given managers and supervisors great control over resources for performance assessment purposes. Consequently, the deployment of officers 
into the hot spots could be monitored, and the movement of the officers, both spatially and temporarily, was closely tracked. The officers' perspective of this tracking capacity is the focus of our study. We were able to compare the views of these officers with those of officers who did not participate in this experiment.

\section{HYPOTHESIZING THE COLLATERAL CONSEQUENCES OF HOT SPOTS POLICING}

The hot spot-policing literature is constantly evolving, in terms of practice and research complexities. While some studies continue to reaffirm the original finding that a saturated police presence at hot spots reduces crime and disorder (Telep, Mitchell, \& Weisburd, 2012), others have begun to look more closely at precisely what type of police presence prevents crimes. For example, some have focused on problem-oriented policing (e.g., Braga \& Bond, 2008; Braga et al., 1999; Weisburd \& Green, 1995; Taylor, Koper, \& Woods, 2011), drug enforcement operations (e.g., Weisburd \& Green, 1995), increased gun searches and seizures (e.g., Sherman \& Rogan, 1995a), foot patrol (Ratcliffe et al., 2011), crackdowns (e.g., Sherman \& Rogan, 2005b), 'zero-tolerance' policing or 'broken windows tactics' (Caeti, 1999; Weisburd et al., 2011), foot patrol conducted by community support police officers in Birmingham South, and proactive policing tactics (Rosenfeld et al., 2014; Taylor et al., 2011).

These hot spot policing approaches come with a cost to officers' autonomy and discretion. For half a century, particularly after the introduction of rapid response policing, frontline officers were given virtually unlimited discretion as to where and when to conduct patrols. When officers were 'between jobs', they were given the liberty to make a professional decision about where to go, with what dosage levels, and with what frequency. This has now changed with directed police patrols; officers are instructed not only where and when to go, but with what frequency. Although far from micromanagement, as officers are 
still allowed to employ their personal style of communication and make decisions regarding arrest, interviews and problem-solving techniques, we nevertheless anticipate that this regimented direction that bounds their spatiotemporal autonomy may have collateral consequences or backfiring effects.

In this respect, it becomes immediately apparent how the systematic tracking of implementation is closely linked to this story. As Sherman (2013) argues, if we want to accurately characterize the effect of this intervention, we also need to be able to measure the extent to which these strategies are being delivered (for extensive discussion on this, see Sherman \& Weisburd, 1995, p. 628). Whether or not these policies are effective depends largely on the degree to which field officers implement them. Tracking these resources is also important if we are interested in cost-benefit ratios, health and safety concerns, and management of resources. Yet tracking of implementation in hot spots experiments has been relatively thin, either on the ground or anecdotal (cf. Rosenfeld et al., 2014; Sherman \& Weisburd, 1995; see also Ariel, Farrar, \& Sutherland, 2015; Ariel et al., 2016a, 2016b). This is largely due to limited research budgets: placing observers at the hot spots to document the implementation of these directed patrol strategies comes with a tremendous cost. Systematic social observations of both treatment and control hot spots are expensive, particularly if one wishes to track the entire lifecycle of the experiment, which could extend longer than 12 months.

These budgetary restrictions have now been lifted by the advent of Global Positioning Systems (GPS) tracking capabilities. The use of GPS to track resources is the newest development in hot spot policing. In the United Kingdom, the use of GPS positioning is now standard in most police forces. The system is located on the Airwave radio terminals, used by all police officers, allowing tracking of each individual officer as well as vehicles (unlike US police departments, who oppose such person-based trackers). The GPS within the Airwave 
radio terminals monitors 24 satellites of which there are usually between six and 12 visible above the horizon at any one time. The Airwave device, as with all GPS receivers, needs to 'see' four of those satellites at any given time. Occasionally, if the radio is amongst tall buildings or inside a building, it may show as loss of GPS. Taking the airwave device to a position where it can 'see' the sky allows the device to lock onto those available satellites. The benefits of this system are seen in a forces' ability to deploy not simply the nearest, but the most appropriate resource to an incident, thus saving time and money and potentially improving performance. Equally importantly, GPS allows police departments to measure how much time officers spend in hot spots to determine whether GPS can be useful for harnessing unallocated patrol time (see Weisburd et al., 2015). With the advent of geofencing, managers can now capture the duration and frequency of patrols within the hot spots. Other than assessing the impact of specific dosages of police presence on crime reduction, the technology provides a way to verify that tasking, patrol strategies, and assignments are carried out by the rank and file.

\section{TAYLORISM AND GPS-TRACKING}

It has been recognized for some time that the introduction of GPS-based tracking technology can limit police discretion and result in greater supervisory scrutiny of officer activity (Chan, 2001; Ericson \& Haggerty, 1997). In a study of Canadian police at the turn of the century the deployment of computer-aided dispatch terminals in police vehicles was viewed negatively by officers because of the ability to monitor exactly what an officer was doing throughout their entire tour of duty, like a Taylorist "time and motion study that never ends" (Ericson \& Haggerty, 1997, p. 396). 
Over 100 years ago, Frederick Winslow Taylor published his Principles of Scientific Management (1911), in which he aimed to revolutionize work and improve productivity by systematically breaking tasks down into very specific, discrete areas which would then be uniformly performed by the worker in an automated way. Towards the end of the twentieth century, not only were private organizations and businesses affected by Taylorism in everything from car production to making hamburgers, but increasingly public sector organizations were also subjected to his scientific principles of efficiency, effectiveness and improved productivity (Bolton, 2004). Many hated this Taylorist approach - particularly the detailed examination and routinization of a worker's activity - leading to strikes and industrial unrest.

GPS data tracking is now allowing police leaders to redesign policing services to reduce cost and improve efficiency. One of the ways in which GPS can be used is to track and measure the exact dosage and number of patrols that an officer undertakes in a hot spot. Whilst the ability to track police patrols has a long history (Wain \& Ariel, 2014), the use of GPS data now allows the police to measure in a very precise way exactly how much patrolling is being done in these hot spots (Sherman et al., 2014).

\section{LINKING IT TOGETHER: INTERPERSONAL RELATIONS AND GPS-TRACKING IN HOT SPOTS POLICING}

The evidence for the effectiveness of hot spots policing is robust. However, there are no studies on its potential effects on officers and their relationships with the police departments. The areas which might feasibly be impacted are as follows: organizational commitment, internal procedural justice, interpersonal trust, and self-legitimacy. Organizational commitment refers to 'the relative strength of the individual's identification with, and involvement in, a particular organization, [ . . ] characterized by three factors: (a) a strong 
sense of belief in, and acceptance of, the organization's goals and values; (b) a readiness to exert effort on behalf of the organization; (c) a strong desire to remain a member of the organization' (Porter et al., 1974, p. 604). Prior research shows that such organizational identification or commitment depends on fair treatment by supervisors (Sholihin \& Pike, 2010; Tankebe, 2010; Bradford et al., 2013).

Internal procedural justice is concerned with the role of judgments about the fairness of procedures in people's everyday reactions to authorities. Procedural justice has two dimensions: quality of decision-making and quality of interpersonal treatment (Tyler \& Blader, 2000). The former comprises a number of discrete judgments: inviting participation in decision-making; offering explanations for decisions; neutrality; and trustworthiness. Quality of interpersonal treatment, on the other hand, describes whether authorities treat people with respect, dignity, and courtesy. Although these issues may seem superficial and inconsequential, each communicates information to citizens about their standing and membership in society (Tyler, 1990). They also raise questions about the character of the system of domination represented by a power-holder.

There is extensive evidence to show that procedural justice matters for social order, both within organizations and in the wider community. For example, management scholars have linked procedural justice to various forms of workplace deviance (Greenberg, 1993). More recently, there is growing evidence from police scholars to show that fair treatment by supervisors motivates officers to comply with directives, to develop a commitment to work, to engage in pro-organizational behavior, and to be predisposed to the fair treatment of citizens (e.g., Haas et al., 2015; Tankebe, 2014; Bradford \& Quinton, 2014; Bradford et al., 2013). As previously argued, GPS allows management to track the movement of officers at hot spots. There is a risk that this system of control might be viewed as intrusive and a violation of privacy to officers. There is also the danger that supervisors might become more 
focused on achieving the assigned dosage of patrols and less concerned about the fairness of the procedures they employ in dealing with officers. As Brown (1988. p. 9) observes, 'patrolmen lead something of a schizophrenic existence: they must cope not only with the terror of an often hostile and unpredictable citizenry, but also with a hostile - even tyrannical - and unpredictable bureaucracy.'

Hot spots policing may have implications for the quality of interpersonal relations among frontline officers. Decades of research on police culture suggest that officers often draw a distinction between 'them' (e.g., citizens and management) and 'us' (mainly, frontline or patrol officers (Skolnick, 1966; Reuss-Ianni \& Ianni, 1983; Chan, 1997). This distinction arises out of 'the need to be able to rely on colleagues in a tight spot' (Reiner, 2010, p. 122). Thus one feature of police work is the ability to rely on colleagues for mutual support and to develop norms of loyalty. This is akin to what Coleman (1988) describes as 'relational social capital'; as Coleman (1988, p. 101) argues, 'a group within which there is extensive trustworthiness and extensive trust is able to accomplish much more than a comparable group without that trustworthiness and trust'. Interpersonal trust and mutual support amongst officers have been found to correlate with self-legitimacy and decisions such as the use of force (Muir, 1977; Tankebe \& Mesko, 2015). GPS-based hot spots may carry the risk of producing a 'siege mentality' - that is, 'a mental state in which members of a group hold a central belief that the rest of the world has highly negative behaviour intensions towards them' (Bar-Tal \& Antebi, 1992, p. 634). Therefore we should expect greater levels of loyalty, mutual support, and solidarity among officers involved in hot spots policing.

Finally, GPS-based tracking at hot spots might also have implications for officer selflegitimacy. Self-legitimacy describes power-holders' recognition of, or confidence in, their own individual entitlement to power; it, therefore, concerns the self-recognition of entitlement to power (Bottoms \& Tankebe, 2012; 2013). Kronman (1983, p. 41) refers to 
Max Weber's argument that power-holders have a need to 'persuade themselves that their fates are deserved and therefore rightful' and that this need not only precedes the attempt to cultivate audience legitimacy, but is also a necessary condition for such an enterprise. To the extent that power-holders anticipate and understand the criticisms of their audiences about their right to that power, the power-holders must already be critics themselves (cf. Kronman 1983, p. 41). In other words, power-holders are not satisfied with being legally mandated to execute certain functions; in addition, they seek to consolidate that power by convincing themselves that such power is morally right (Bottoms \& Tankebe, 2012).

Barker (2001) argues that self-legitimacy involves a quest for prestige and the cultivation of a unique identity distinguishable from that of ordinary citizens. There is evidence from ethnographic studies to show that police officers describe a similar quest for uniqueness and separation. As Herbert (2006, p. 488) reports, officers see themselves as 'the professional experts whose knowledge and skill deserve deference'. Thus, he observed that:

Officers at community forums [in Seattle] similarly deflect citizen input, and retain strong control of the dialogues that do occur. They leave little doubt about their self-construction vis-a-vis the public: they best understand the dynamics of crime and disorder; they uniquely possess the tools and strategic knowledge to address those dynamics. (p. 488)

Hot spots policing, especially the use of GPS to track officers, may be viewed as an unnecessary encroachment upon their autonomy and expertise. Such perceived interference has the potential to undermine officers' sense of self-legitimacy. It is, therefore, our hypothesis that officers involved in hot spots policing will report lower levels of selflegitimacy than those not involved in hot spots policing. Of course, it may also be possible that officers welcome the effort to use evidence to accomplish their objectives. However, as some researchers have observed, officers have historically not believed that those outside 
the policing profession would assist them in performing their duties, and even if 'outsiders' did try to assist, they would not be of any real help (Sparrow et al., 1990).

\section{THE BIRMINGHAM SOUTH HOT SPOTS EXPERIMENT}

An opportunity existed during a large-scale experiment in which officers were heavily tracked using GPS technology (Ariel et al., 2014). West Midlands Police have tested the effect of police foot patrols in the most chronic and severe hot spots of crime and anti-social behavior in the region of Birmingham South $(n=79)$. These areas of 150 meters in radius attracted no less than 36 offences in the preceding 12 months of the experiment. Importantly, the locations were plotted on the command-and-control database to capture geospatial data on the patrol movement in and out of the hot spots, thus allowing for the measurement of time spent by each officer at each location. This type of assessment of the geographical information system is often referred to as 'point-in-polygon' (PIP) analysis.

Half of the hot spots were randomly allocated to experimental conditions: additional foot patrol by police officers of 15-minute visits, at least three times per shift. Officers were instructed to visit the hot spots in a regimented way for the entire duration of the experiment (November 2012 - November 2013). In other words, unlike other officers not in Birmingham South, officers may or may not have been directed to patrol a crime 'area', but these directions were not regulated to the degree or with the same rigor as the officers patrolling hot spots in Birmingham South. The experiment required them to patrol in a very precise way, ensuring that they achieve a specific number of visits as well as the appropriate duration. 
GPS trackers through Airways were used to accurately track where officers were located, as well as to enhance their sense of security, given that some of these hot spots might be high-risk. This enables managers to create a detailed report that can not only be used to examine the effectiveness of the patrol, but also to discuss with each officer their compliance with the task.

\section{METHODS AND DATA FOR THE PRESENT STUDY}

As a part of the Birmingham South Foot Patrol Experiment, the officers were asked to complete a survey on their perceptions, attitudes and feelings about this management surveillance. A survey developed specifically for the purposes of this study, consisting of 86 questions, was sent physically to every officer who had taken part in the experiment in Birmingham South Local Policing Unit (LPU; $n=67$ ). In order to assess how officers perceive this management surveillance, we have also contacted all the officers who conduct foot patrol in another LPU within West Midlands - Coventry $(n=89)$ where the experiment was not conducted. We chose a different LPU to avoid contamination of the 'control site' (see Sampson, 2010) because the same officers would have patrolled the treatment hot spots and the control hot spots within Birmingham. Foot patrols were conducted at high crime areas in the control site; however, these were somewhat random and there was no tracking of officers with GPS.

We also warn that the sample size is relatively low and results should therefore be interpreted with caution; however, these numbers represent the entire populations of relevant officers available in these two LPUs. We achieved an overall $51 \%$ response rate, broken down into 38 out of 67 in Birmingham South and 42 out of 89 respondents, which is normal for paper-based, mail order surveys (see Nulty, 2008). We are unable to conduct any further 
analyses on the missing at random nature of the non-respondents (Altman, 2003), as we did not obtain permission to ask personal questions beyond the age and gender of officers. However, when compared to the population of officers in England and Wales, there are no statistically significant differences between these two characteristics and our sample. Additional baseline comparisons between the two LPUs are presented in Table 1 below along with information on England and Wales more broadly. We address these baseline comparisons in our discussion chapter.

\section{INSERT TABLE 1 HERE}

\section{VARIABLES}

Prior to developing the scales, a factor analysis was conducted to test for the assumed conceptual differentiation between the variables used to construct the scales. A principal component factor analysis was conducted on the items. The Kaiser-Meyer-Oklin measure confirmed the sampling adequacy for the analysis, $\mathrm{KMO}=.93$. The six items extracted explained $52.83 \%$ of the variance. The results, as displayed in Table 2, reveal five constructs. Two items were found to cross-load on different scales and were removed from the analysis.

Internal Procedural Justice. As shown in Table 2, nine items measured officers' assessments of procedural justice within their organizations. These included 'The decisions of my supervisor are equally fair to every officer' and 'I feel my supervisor treats me with respect and dignity'. We used a five-point Likert scale, with responses ranging from 1 (strongly disagree) to 5 (strongly agree). A higher score reflects more positive assessments 
$($ Cronbach's alpha: treatment $=.94$ and control $=.94 ;$ mean $=3.81 ;$ standard deviation $(\mathrm{SD})=$ $.96)$.

Relations with colleagues. Five items were used to assess the quality of interpersonal relations amongst officers: for example, 'I feel supported by my colleagues' and 'I find it hard to trust my colleagues' (reversed coded). Answers were given on a five-point Likert scale, with responses ranging from 1 (strongly disagree) to 5 (strongly agree), with a higher score reflecting more positive assessments of relations among officers. The overall scale was reliable at both treatment site $($ Cronbach's alpha $=.95)$ and control site Cronbach's alpha $=$ $.88) ;$ mean $=3.91, \mathrm{SD}=91$.

Organizational Commitment. Seven items were employed to gauge levels of organizational commitment amongst the officers. These included: 'I find real enjoyment in my job' and 'I feel that my police force deserves my loyalty'. We used a five-point Likert scale, with responses ranging from 1 (strongly disagree) to 5 (strongly agree), with higher scores reflecting greater levels of organizational commitment. The overall scale was reliable at both treatment site (Cronbach's alpha $=.82)$ and control site (Cronbach's alpha $=.77)$; mean $=3.69, \mathrm{SD}=67$.

Attitudes towards Hot spots Policing. This was measured with four items. Sample items include 'I find 15-minute hot spots patrols useful' and '15-minute patrols are an effective use of my time on duty.' We used a five-point Likert scale, with responses from 1 (strongly disagree) to 5 (strongly agree), with a higher score indicating more positive assessments. (Cronbach's alpha: treatment $=.82$ and control $=.52 ;$ mean $=2.49 ; \mathrm{SD}=.84$ ).

Finally, we used three items to measure officers' self-legitimacy. These included: 'I believe I occupy a special position in society' and 'The powers I have as a PC are morally right'. Responses were recorded on a five-point Likert scale, with responses ranging from 1 
(strongly disagree) to 5 (strongly agree), such that a higher score reflected greater selflegitimacy (Cronbach's alpha: treatment $=.77$ and control $=.68 ;$ mean $=3.16 ; \mathrm{SD}=.84$ ).

INSERT TABLE 2 HERE

\section{FINDINGS}

Mann-Whitney $U$ tests were used to compare the treatment and control groups on five measures: internal procedural justice, organizational commitment, relations with colleagues, receptivity to hot spots policing, and self-legitimacy. The Mann-Whitney $U$ test is a nonparametric test of the similarity of the distribution of a variable between two groups (Field, Miles, \& Field, 2012). The Mann-Whitney U test results are shown in Table 3.

We begin with receptivity to hot spots policing. The results show that officers at the hot spots $(M=31.33)$ held less positive attitudes than officers not involved in hot spots policing $(M=48.8, U=449.5, z=-3.38, p \leq .001)$. We also disaggregated the combined index for receptivity to hot spots and compared the views of the officers across each of the four measures employed to create the index. Officers at the treatment sites perceived 15minute hot spot patrols as less useful $(M=31.78)$ than those at the control sites $(M=48.39$, $U=466.5, z=0-3.32, p \leq .001)$. Further, officers at the treatment sites $(M=30.01)$ were less likely than officers at the control sites to consider hot spots policing as an effective tactic for targeting incidents $(M=49.99, U=399.5, z=0-3.95, p \leq .001)$. However, in comparison with hot spots officers $(M=33.79)$, officers at the control sites $(M=46.57)$ were statistically more predisposed to believe hot spots policing curtailed their discretion to determine the places to patrol $(U=543, z=-2.59, p \leq .01)$. The only measure on which both officers did not differ statistically was whether 15-minute patrols were an effective use of their time on 
duty $(U=717.0, z=-.82, p>.05)$.

Next, we examined possible backlash effects of hot spots policing on internal procedural justice. As shown on Table 3, internal procedural justice ratings were lower among hot spots officers $(M=33.86)$ than officers at the control sites $(M=46.51, U=545.5$, $z=-2.44, p \leq .05)$. Hot spots officers were statistically more likely to believe supervisors made decisions based on personal biases $(U=586, z=-2.15, p \leq .05)$, assigned duties unfairly $(U=582.5, z=-2.15, p \leq .05)$, failed to inspire them $(U=525, z=-2.73, p \leq .01)$, hardly ever offered explanations for decisions that affected officers $(U=562.5, z=-2.42, p$ $\leq .02)$, and did not take their needs into account when making decisions ( $U=600.5, z=-$ 2.02, $p \leq .02)$. These five elements capture what Tyler and Blader (2000) describe as 'quality of decision-making'. The other dimension of internal procedural justice is 'quality of interpersonal treatment', which concerns respectful treatment. On this measure, hot spots officers $(M=37.30)$ did not differ significantly from non-hot spots officers $(\mathrm{M}=43.39, U=$ $676.5, z \leq-1.28, p>.05)$

Contrary to expectations, the two groups did not differ on the other dimensions measured. Thus, with respect to the quality of interpersonal relations, we found no statistically significant difference between hot spot officers $(M=39.99)$ and officers who did not participate in hot spots policing $(M=40.96), U=.778 .5, z=-.19, p \leq .05$. For example, hot spots policing did not affect interpersonal trust $(U=675.0, z=-1.25, p \leq .05)$ or the levels of support they received from their colleagues $(U=666.5, z=-1.32, p \leq .05)$. There were also no differences between the officers in terms of organizational commitment $(U=650, z=-$ $1.43, p \leq .05)$. Both sets of officers were equally inclined to report they enjoyed their jobs ( $p$ $\leq .05)$ and felt enthusiastic about the job $(p \leq .05)$. However, they differed on one measure of organizational commitment: in comparison with non-hot spots officers $(M=45.56)$, hot spots officers $(M=34.91)$ were statistically less likely to believe their values were similar to those 
of the organization $(U=585.5, z=-2.18, p \leq .05)$.

Finally, the data show that levels of self-legitimacy among hot spot officers $(M$ $=42.39)$ did not differ significantly from non-hot spot officers $(M=38.79, U=726, z=-$. $70, p \leq .05$.

\section{INSERT TABLE 3 HERE}

\section{DISCUSSION}

There is now a strong body of scientific evidence showing that the placement of police patrols in very specific high crime locations can reduce crime and calls for service (Braga et al., 2012; Braga et al., 2014). Our study sought to examine one concern associated with hot spots policing - namely officers' receptivity to hot spots policing and the impact of GPS-led hot spots policing on social relations. A number of findings emerged from our analysis. In the main, too few studies of policing tactics have included unintended effects in general, and even fewer examine negative effects they may have on officers. This is key as any negative impacts can hurt implementation and thus undermine the effectiveness of tactics, so our ability to evaluate them should be considered.

First, there is some evidence from research by psychologists to show that 'knowledge and liking within individuals is in fact negative: that more information about any one person leads, on average, to less liking for that person' (Norton, Frost, \& Ariely 2007, p. 97). Our findings regarding police attitudes to hot spots policing appear to confirm this hypothesis. Specifically, we found that officers with direct knowledge of hot spots policing were generally less likely to express positive attitudes about it. Such officers did not perceive the duration set in the experiment as useful. 
The officers in the operational area of South Birmingham clearly dislike the routinization of their shifts through the use of the 15-minute patrols and feel very strongly that this removes their discretion and initiative. It is clear that, like other technological innovation, the introduction of GPS tracking reduces the autonomy and discretion that patrolling officers once had, placing them under a Taylorist-type regime not previously experienced. Poor briefings and a lack of direction by some sergeants on what activities to undertake in the hot spot were evident from the survey. Special tasking sheets, consisting of tasks, intelligence requirements and active offenders, which were intended to allow sergeants to give clarity to their staff on objectives, quickly fell into disrepute. Just one month after their introduction, only one sergeant was updating these and providing new guidance and updates to their patrolling officers.

Second, we found evidence that hot spots policing was detrimental for internal procedural justice. Officers who participated in the hot spots were less likely to rate procedural justice treatment from their supervisors highly. However, an interesting finding emerged when we disaggregated the combined internal procedural justice index. We found that the negative effects of hot spots policing was restricted to what Tyler (2003) calls quality of decision-making; it did not affect the quality of interpersonal relations. Nonetheless, as Tyler and his colleagues have consistently found, internal procedural justice is an essential resource for police departments. Lind and Tyler (1988, p. 179) summarize the evidence as follows:

Procedural justice is a remarkably potent determinant of affective reactions to decision making and that procedural justice has especially strong effects on attitudes about institutions and authorities, as opposed to attitudes about a specific outcome in question. . . [A]ttitudes toward the organization as a whole, including such things as organizational commitment, loyalty and 
work group cohesiveness, are strongly affected by procedural justice judgment.

Third, there was evidence that hot spots policing did not undermine officers' normative commitments to the police organization. However, further analysis revealed that it had negative consequences for one out of the seven items we used to measure organizational commitment: 'I have found that my values and my organization's values are similar'. This item captures what Jackson and his colleagues (Jackson et al., 2012) call 'moral alignment'. Originally used in the context of police-citizens relations, moral alignment refers to 'a sense of shared moral values and group solidarity with the police... a sense of shared moral purpose' (p. 13). Within our present context, a focus on 'What works?' in crime reduction (e.g., hot spot policing) may have the unintended consequence of undermining the normative identification or attachment between officers and the organization.

\section{Limitations}

There are several drawbacks of this study. The greatest weakness is in the study's research design. The treatment and control groups have not been randomized. In addition, the survey measures are post-intervention only. Hence, the study design is a non-randomized (i.e., nonequivalent) post-only control group design. This makes it challenging in terms of internal validity - that is, to know whether the differences observed between the treatment and control groups were caused by the intervention. For example, the treatment and control officers may have had significant differences in their views before the hot spots program, perhaps due to differences in their assignments and managers. In other words, the two groups of officers could not be compared beyond age and gender to give us any sense of the quality of the 
comparison. This issue is greater because LPUs are known for having very different types of officers in terms of work, attitude, and leadership. On the other hand, since the introduction of GPS tracking and hot spots policing can be construed as such a radical transformation in the way officers conduct their patrols, we remain encouraged that the data reflect changes due to the treatment, not pre-test differences. Still, threats to validity are real, and future research in this area would benefit from randomised controlled designs rather than the methodology we used herein. Alternatively, in place of officer-level variables, it is imperative that future studies compare LPU-level variables such as size, urbanness, population makeup, crime type, leadership structures, and other factors that could impact officer attitudes. Similarly, some forces conduct a survey of officer opinions or ideas about topics such as leadership or the direction of the organization, and using those comparisons would be useful to show whether there are differences in terms of officer attitudes.

Second, the type of hot spots policing used in Birmingham (i.e., a style in which officers are given very specific directives about where to visit, how many times, and for how long) constitutes just one particular method of hot spots policing. In practice, hot spots policing includes a wide variety of patrol and other interventions focused on high-risk locations. In order to generalize to other types of patrols within hot spots, more attention should be paid in future studies to other types of place-based interventions. In this respect, considering the most effective tactics in addressing these places, many departments are encouraging police officers to consider what would be effective interventions in dealing with risky places (for example, see Rosenfeld et al., 2014), thereby increasing their commitment to the interventions (see Dugato, 2013 and Kennedy et al., 2015).

Finally, the negative results could be interpreted in two ways, and we have no way of disentangling this in a causal way: were the outcomes driven by the concept of directed patrols, or by the GPS tracking, or the interaction of both? It may be that officers do not like 
being monitored all the time, and/or that they do not like to lose their discretion about where and when to patrol. We suspect it is the combination of the two; however, our data do not allow us to make such a direct conclusion. Future studies, especially in light of the growing use of GPS tracking of police resources, will want to pay close attention to this minute yet important distinction.

\section{Conclusions}

Police leaders deploying this tactic will need to be much more cognizant of its impact upon the actors if they are to avoid potential adverse effects. Implementation is critical to the successful delivery of any intervention. Whilst scientifically evaluated and evidence-based police interventions have improved, the same cannot be said for the scientific evaluation of the implementation of those interventions (Fixen et al., 2005). Although it is not new that those who do the policing and those that provide the leadership may have conflicting views (Cockcroft, 2014; Reuss-Ianni \& Ianni, 1983), this study has highlighted the need for police leaders to consider the attitude of staff towards hot spot policing and how frontline leaders supervise those involved in the implementation of hot spot policing, if they are to avoid a negative impact upon organizational commitment and ultimately enjoy a successful outcome.

Our findings highlight the need to embrace, endorse and cultivate officer buy-in and belief in the tactic before hot spots studies begin. Some researchers have argued for police to take 'ownership' of science if innovations are to be successfully implemented and evaluated (Sherman et al., 2014; Neyroud \& Weisburd, 2014; Weisburd \& Neyroud, 2011). However, it is important to recognise potential adverse effects. We recommend law enforcement agencies who look into implementing a hot spots patrol program to avoid or minimize the negative effects on officer attitudes by informing them, ex ante, what they ought to expect from these tactics. For instance, officers need to be aware that GPS tracking is not for additional 
supervision or micro-management, but rather about following the data where crime is more heavily concentrated, and that targeting these places is efficient and cost-effective. Better communications and continuous involvement in decision-making are likely to mitigate some of the issues officers have raised in relation to both tracking as well as hot spots policing more broadly. 


\section{REFERENCES}

Ariel, B. (2014, July). A direct test of 'local deterrence' and 'deterrence radiation': The London Bus Experiment. Paper presented at the University of London International Crime Science Conference, British Library.

Ariel, B., Farrar, W. A., \& Sutherland, A. (2015). The effect of police body-worn cameras on use of force and citizens' complaints against the police: A randomized controlled trial. Journal of Quantitative Criminology, 31(3), 509-535.

Ariel, B., \& Partridge, H. (2016). Predictable policing: Measuring the crime control benefits of hot spots policing at bus stops. Journal of Quantitative Criminology, 1-25.

Ariel, B., Sutherland, A., Henstock, D., Young, J., Drover, P., Sykes, J., Drover, P., Sykes, J., Megicks, S. \& Henderson, R. (2016a). Report: increases in police use of force in the presence of body-worn cameras are driven by officer discretion: a protocol-based subgroup analysis of ten randomized experiments. Journal of Experimental Criminology, 1-11

Ariel, B., Sutherland, A., Henstock, D., Young, J., Drover, P., Sykes, J., Drover, P., Sykes, J., Megicks, S. \& Henderson, R. (2016b). Wearing body-cameras increases assaults against officers and does not reduce police-use of force: Results from a global multisite experiment. European Journal of Criminology,

Ariel, B., Weinborn, C., \& Sherman, L. (2016). Soft policing at hot spots - does it work? A randomized controlled trial. Journal of Experimental Criminology, 1-41

Bar-Tal, D., \& Antebi, D. (1992). Beliefs about negative intentions of the world: A study of the Israeli siege mentality. Political Psychology, 13(4), 633-645. 
Bottoms, A., \& Tankebe, J. (2012). Beyond procedural justice: A dialogic approach to legitimacy in criminal justice. Journal of Criminal Law and Criminology, 102, 119170.

Bottoms, A., \& Tankebe, J. (2013). "Voice within": Powerholders' perspectives on authority and legitimacy. In J. Tankebe and A. Liebling (eds.), Legitimacy and criminal justice: An international exploration. Oxford: Oxford University Press.

Bradford, B., Quinton, J., Myhill, A., \& Porter, G. (2013). Why do 'the law' comply? Procedural justice, group identification and officer motivation in police organizations. European Journal of Criminology, 11(1), 110-131.

Bradford, B., \& Quinton, P. (2014). Self-legitimacy, police culture and support for democratic policing in an English constabulary. British Journal of Criminology, $54(6), 1023-1046$.

Brown, M. K. (1988). Working the street: Police discretion and the dilemmas of reform. New York: Russell Sage Foundation.

Chan, J. (1996). Changing police culture. British Journal of Criminology, 36, 109-134.

Chermak, S., McGarrell, E., \& Weiss, A. (2001). Citizens' perceptions of aggressive traffic enforcement strategies. Justice Quarterly, 18, 365-391

Cockcroft, T. (2014). Police culture and transformational leadership: Outlining the contours of a troubled relationship. Policing, 8(1), 5-13.

Dugato, M. (2013). Assessing the validity of risk terrain modeling in a European city: Preventing robberies in the city of Milan. Crime Mapping, 5(1), 63-89.

Ericson, R. V., \& Haggerty, K. D. (1997). Policing the risk society, Oxford. Clarendon Press. 
Fixen, D. L, Naoom, S. F, Blase, K. A, Friedman, R. M., \& Wallace, F. (2005). Implementation research: A synthesis of the literature. Tampa. University of Florida.

Haas, N. E., Van Craen, M., Skogan, W. G., \& Fleitas, D. M. (2015). Explaining officer compliance: The importance of procedural justice and trust inside a police organization. Criminology and Criminal Justice, 15(4), 442-463.

Herbert, S. (2006). Tangled up in blue: Conflicting paths to police legitimacy. Theoretical Criminology, 10, $481-504$.

Jackson, J., Bradford, B., Stanko, B., \& Hohl, K. (2012). Just Authority? Trust in the police in England and Wales. Oxford: Routledge.

Kennedy, L. W., Caplan, J. M., Piza, E. L., \& Buccine-Schraeder, H. (2015). Vulnerability and exposure to crime: Applying risk terrain modeling to the study of assault in Chicago. Applied Spatial Analysis and Policy, 1-20.

Kochel, T. R. (2011). Constructing hot spots policing: Unexamined consequences for disadvantaged populations and for police legitimacy. Criminal Justice Policy Review, 22(3), 350-374.

Koper, C. S. (1995). Just enough police presence: Reducing crime and disorderly behavior by optimizing patrol time in crime hot spots. Justice Quarterly, 12, 649-672.

Kronman, A. (1983). Max Weber. London: Edward Arnold Publishers Ltd.

Lind, E. A. \& Tyler, T. (1988). The social psychology of procedural justice. New York: Plenum.

Neyroud, P., \& Weisburd, D. (2014). Transforming the police through science: The challenge of ownership. Policing, 8(4), 287-293. 
Norton, M. I., Frost, J. H., \& Ariely, D. (2007). Less is more: The lure of ambiguity, or why familiarity breeds contempt. Journal of Personality and Social Psychology, 92, 97105.

Nulty, D. D. (2008). The adequacy of response rates to online and paper surveys: What can be done? Assessment \& Evaluation in Higher Education, 33(3), 301-314.

Porter, L. W., Steers, R. M., Mowday, R. T., \& Boulian, P. V. (1974). Organizational commitment, job satisfaction and turnover among psychiatric technicians. Journal of Applied Psychology, 59, 603-609.

Reuss-Ianni, E., \& Ianni, F. (1983). Street cops and management cops: The two cultures of policing. In M. Punch (Ed.), Control in the Police Organization (pp. ). Cambridge, MA: MIT Press.

Rosenbaum, D. P. (2006). The limits of hot spots policing. In D. Weisburd \& A. A. Braga (Eds.), Police innovation: Contrasting perspectives (pp. ). Cambridge: Cambridge University Press.

Rosenfeld, R., Deckard, M. J., \& Blackburn, E. (2014). The effects of directed patrol and self-initiated enforcement on firearm violence: A randomized controlled study of hot spot policing. Criminology, 52(3), 428-449.

Sherman, L. W., \& Weisburd, D. (1995). General deterrent effects of police patrol in crime "hot spots": A randomized, controlled trial. Justice Quarterly, 12(4), 625-648.

Sherman, L. W., Williams, S., Ariel, B., Lucinda R., Strang, L. R., Wain, N., ... Norton, A. (2014). An integrated theory of hot spots patrol strategy: Implementing prevention by scaling up and feeding back. Journal of Contemporary Criminal Justice, 30(2), 95122. 
Sholihin, M., \& Pike, R. (2010). Organizational commitment in the police service: Exploring the effects of performance measures, procedural justice, and interpersonal trust. Financial Accountability \& Management, 26(4), 392-421.

Skolnick, J. (1966). Justice without trial. New York: John Wiley and Sons.

Tankebe, J. (2014). The Making of democracy's champions: Police support for democracy in Ghana. Special Issue of Criminology \& Criminal Justice, 14(1), 25-43.

Tankebe, J., \& Meško, G. (2015). Police self-legitimacy, use of force, and pro-organizational behavior in Slovenia. In G. Meško \& J. Tankebe (Eds.), Trust and legitimacy European perspectives (pp. ). New York: Springer.

Taylor, F. W. (1911). The principles of scientific management. New York, NY: Harper \& Brothers.

Tyler, T. R., \& Blader, S. (2000). Cooperation in groups: Procedural justice, social identity, and behavioral engagement. Philadelphia, PA: Psychology Press.

Tyler, T., Callahan, P., \& Frost, J. (2007a). Armed, and dangerous(?): Motivating rule adherence among agents of social control. Law \& Society Review, 41, 457-492.

Tyler, T. R, Callahan, P., \& Frost, J. (2007b). Armed, and dangerous(?): Can self-regulatory approaches shape rule adherence among agents of social control? Law and Society Review, 41(2), 457-492.

Wain, N., \& Ariel, B. (2014). Tracking of police patrol. Policing 8(3), 274-283.

Weisburd, D., Bushway, S., Lum, C., \& Yang, S. M. (2004). Trajectories of crime at places: A longitudinal study of street segments in the city of Seattle. Criminology, 42(2), 283322.

Weisburd, D., Groff, E. R., Jones, G., Cave, B., Amendola, K. L., Yang, S.-M., \& Emison, R. 
F. (2015). The Dallas patrol management experiment: Can AVL technologies be used to harness unallocated patrol time for crime prevention? Journal of Experimental Criminology, doi 10.1007/s11292-015-9234-

Weisburd, D., Hinkle, J. C., Famega, C., \& Ready, J. (2011). The possible "backfire” effects of hot spots policing: An experimental assessment of impacts on legitimacy, fear and collective efficacy. Journal of Experimental Criminology, 7, 297-320.

Weisburd, D., \& Neyroud, P. (2011). Police science: Towards a new paradigm. New perspectives in policing. Harvard Executive Session in Policing. Cambridge: MA.

Weisburd, D., Wyckoff, L. A., Ready, J., Eck, J. E., Hinkle, J. C., \& Gajewski, F. (2006). Does crime just move around the corner? A controlled study of spatial displacement and diffusion of crime control benefits. Criminology, 44(3), 549-592. 
Table 1: Baseline Comparability: Treatment and Comparison LPUs:

\begin{tabular}{llll} 
Force & \multicolumn{2}{c}{ West Midlands } & England and Wales \\
LPU & Birmingham South & Coventry & Total \\
N of participating officers & 67 & 89 & \\
Population figures & 301,000 & 316,000 & $55,241,000$ \\
Household figures & 127,000 & 129,000 & $23,254,000$ \\
Violence against the person offences recorded & 3,777 & 4,515 & 762,515 \\
Violence against the person offences per 1,000 population & 12.5 & 14.0 & 14.000 \\
Robbery offences recorded & 787 & 634 & 74,690 \\
Robbery offences per 1,000 population & 2.6 & 2.0 & 1.0 \\
Burglary dwelling offences recorded & 2,164 & 2,502 & 245,317 \\
Burglary dwelling offences per 1,000 population & 7.2 & 8.0 & 4.0 \\
Theft of a motor vehicle offences recorded & 752 & 554 & 92,057 \\
Theft of a motor vehicle offences per 1,000 population & 2.4 & 2.0 & 2.0 \\
Theft from a vehicle offences recorded & 2,035 & 2,242 & 300,377 \\
Theft from a vehicle offences per 1,000 population & 6.7 & 7.0 & 5.0 \\
\hline
\end{tabular}

Source: Police recorded crime 2011/12, Home Office http://www.ons.gov.uk/ons/rel/crime-stats/crime-statistics/period-endingmarch-2012/rft-recorded-crime-tables-2011-12.xls 
Internal Procedural Justice (Variance explained: 22.84\%)

1. The decisions of my supervisor are equally fair to every officer. $\quad .902$

2. Decisions by my supervisor are always based on facts, not personal biases. 878

3. I feel that the way my supervisor assigns duties is fair to all officers in my rank. 855

4. My supervisor inspires the best in me to do my job. $\quad 842$

$\begin{array}{ll}\text { 5. I feel that my supervisor treats me with respect and dignity. } & .837\end{array}$

6. My supervisor takes account of my needs when making decisions that affect me. 835

7. My supervisor usually gives me an explanation for the decisions s/he makes that affect me. $\quad .818$

8. Sergeants/line managers utilize officers of my rank effectively. $\quad .610$

9. Sergeant/line managers regularly brief me on my hot spot visit $\quad .604 *$

10. I am treated fairly in my police force. $\quad .451$

Relations with Colleagues (variance explained: 9.65\%)

11. My PC colleagues treat me with respect. $\quad .891$

12. I have a good working relationship with PC colleagues in my police station. 869

$\begin{array}{ll}\text { 13. I feel that my PC colleagues trust me. } & .844\end{array}$

$\begin{array}{lr}\text { 14. I feel supported by my PC colleagues. } & .841\end{array}$

$\begin{array}{ll}\text { 15. I find it hard to trust my PC colleagues. } & .702\end{array}$

Commitment (Variance explained $=8.51 \%)$ 
16. I find real enjoyment in my job.

.787

17. Most days, I feel enthusiastic about my job.

.764

18. I feel that my police force deserves my loyalty.

19. I often find it hard to convince myself that my role as an officer is necessary.

20. I have found that my values and my organization's values are very similar.

21. I feel a strong sense of belonging to my police force

22. I believe my role as an officer is necessary to prevent crime.

23. I am not entirely sure that my powers as an officer are necessary to make the local community safe.

Hot spot policing (variance explained: $6.51 \%$ )

24. I find the 15-minute hot spot (Op Savvy) patrols useful.

25. Hot spot policing (i.e., Op Savvy) is an effective tactic for officers to target crime and incidents.

26.15-minute patrols are an effective use of my time on duty.

27. 15-minute hot spot patrols take away my initiative and discretion as to where the best place to patrol is.

Self-legitimacy (variance explained: 5.32\%)

28. I believe I occupy a special position in society.

29. When on duty, I feel that I have a special kind of authority.

30. The powers I have as an officer are morally right.

.595

Principal components factoring with varimax rotation. Only loadings $>0.40$ be found in Table 1 . * denotes cross-loading onto two factors 
Table 3: Mann-Whitney U Tests

\begin{tabular}{|c|c|c|c|c|c|}
\hline & Group & $\begin{array}{l}\text { Mean } \\
\text { Rank }\end{array}$ & $\begin{array}{l}\text { Mann- } \\
\text { Whitney U }\end{array}$ & $\mathbf{Z}$ & $p$ value \\
\hline Internal Procedural Justice & & $\begin{array}{l}33.86 \\
46.51\end{array}$ & 545.5 & -2.44 & .02 \\
\hline 1. The decisions of my supervisor are equally fair to every officer. & $\begin{array}{l}\mathrm{BS} \\
\mathrm{CV}\end{array}$ & $\begin{array}{l}35.87 \\
44.69\end{array}$ & 622.00 & -1.81 & .07 \\
\hline 2. Decisions by my supervisor are always based on facts, not personal biases. & $\begin{array}{l}\mathrm{BS} \\
\mathrm{CV}\end{array}$ & $\begin{array}{l}34.92 \\
45.55\end{array}$ & 586 & -2.15 & .03 \\
\hline 3. I feel that the way my supervisor assigns duties is fair to all officers of my rank. & $\begin{array}{l}\mathrm{BS} \\
\mathrm{CV}\end{array}$ & $\begin{array}{l}34.83 \\
45.63\end{array}$ & 582.5 & -2.15 & .03 \\
\hline 4. My supervisor inspires the best in me to do my job. & $\begin{array}{l}\mathrm{BS} \\
\mathrm{CV}\end{array}$ & $\begin{array}{l}33.32 \\
47.00\end{array}$ & 525 & -2.73 & .01 \\
\hline 5. I feel that my supervisor treats me with respect and dignity. & $\begin{array}{l}\mathrm{BS} \\
\mathrm{CV}\end{array}$ & $\begin{array}{l}37.30 \\
43.39\end{array}$ & 676.5 & -1.28 & .20 \\
\hline 6. My supervisor takes account of my needs when making decisions that affect me. & $\begin{array}{l}\mathrm{BS} \\
\mathrm{CV}\end{array}$ & $\begin{array}{l}35.30 \\
45.20\end{array}$ & 600.5 & -2.02 & .04 \\
\hline 7. My supervisor usually gives me an explanation for the decisions s/he makes that affect me. & $\begin{array}{l}\mathrm{BS} \\
\mathrm{CV}\end{array}$ & $\begin{array}{l}34.30 \\
46.11\end{array}$ & 562.5 & -2.42 & .02 \\
\hline 8. Sergeants/line managers utilize officers of my rank effectively. & $\begin{array}{l}\mathrm{BS} \\
\mathrm{CV}\end{array}$ & $\begin{array}{l}38.11 \\
42.67\end{array}$ & 707 & -.92 & .36 \\
\hline 9. I am treated fairly in my police force. & $\begin{array}{l}\mathrm{BS} \\
\mathrm{CV}\end{array}$ & $\begin{array}{l}36.00 \\
44.57\end{array}$ & 627 & -1.76 & .08 \\
\hline Colleagues & & $\begin{array}{l}39.99 \\
40.96\end{array}$ & 778.5 & -.19 & .85 \\
\hline 10. My PC colleagues treat me with respect. & BS & 41.86 & 746.5 & -.52 & .60 \\
\hline
\end{tabular}


11. I have a good working relationship with PC colleagues in my police station.

CV $\quad 39.27$

12. I feel that my PC colleagues trust me.

BS $\quad 36.95$

CV $\quad 43.71$

13. I feel supported by my PC colleagues.

\section{Commitment}

15. I find real enjoyment in my job.

16. Most days, I feel enthusiastic about my job.

17. I feel that my police force deserves my loyalty.

18. I often find it hard to convince myself that my role as an officer is necessary.

19. I have found that my values and my organization's values are very similar.

20 I believe my role as an officer is necessary to prevent crime.

CV $\quad 45.56$

BS $\quad 38.55$

CV

21. I am not entirely sure that my powers as an officer are necessary to make the local

BS

42.26

$\begin{array}{lll}663.0 & -1.39 \quad .16\end{array}$

$\begin{array}{lll}724.5 & -.76 \quad .45\end{array}$

$\begin{array}{lll}666.5 & -1.32 \quad .19\end{array}$

$\begin{array}{lll}675.0 & -1.25 \quad .21\end{array}$

$\begin{array}{lll}650.5 & -1.43 \quad .15\end{array}$

$\begin{array}{lll}707 & -.94 \quad .35\end{array}$

$\begin{array}{lll}689 & -1.12 \quad .26\end{array}$

$678.5-1.21 \quad .23$

$\begin{array}{lll}771.0 & -.28 & .78\end{array}$

$\begin{array}{lll}585.5 & -2.18 \quad .03\end{array}$

$\begin{array}{lll}724.0 & -.80 \quad .43\end{array}$

$\begin{array}{lll}704 & -.93 & .35\end{array}$

$\begin{array}{llll}31.33 & 449.5 & -3.38 & .00\end{array}$ 


\begin{tabular}{|c|c|c|c|c|c|}
\hline \multirow{3}{*}{ 22. I find the 15-minute hot spot (Op Savvy) patrols useful. ${ }^{1}$} & \multicolumn{3}{|c|}{48.80} & \multirow{3}{*}{-3.32} & \multirow{3}{*}{.00} \\
\hline & BS & 31.78 & 466.5 & & \\
\hline & $\mathrm{CV}$ & 48.39 & & & \\
\hline \multirow{2}{*}{$\begin{array}{l}\text { 23. Hot spot policing (i.e., Op Savvy) is an effective tactic for officers in my ran to target } \\
\text { crime and incidents. }\end{array}$} & $\mathrm{BS}$ & 30.01 & 399.5 & -3.95 & .00 \\
\hline & $\mathrm{CV}$ & 49.99 & & & \\
\hline \multirow[t]{2}{*}{ 24. 15-minute patrols are an effective use of my time on duty. } & $\mathrm{BS}$ & 38.37 & 717.0 & -.82 & .41 \\
\hline & $\mathrm{CV}$ & 42.43 & & & \\
\hline \multirow{2}{*}{$\begin{array}{l}\text { 25. } 15 \text {-minute hot spot patrols take away my initiative and discretion as to where the best } \\
\text { place to patrol is. }\end{array}$} & $\mathrm{BS}$ & 33.79 & 543.0 & -2.59 & .01 \\
\hline & $\mathrm{CV}$ & 46.57 & & & \\
\hline \multirow[t]{2}{*}{ Self-legitimacy } & & 42.39 & 726.0 & -.70 & .48 \\
\hline & & 38.79 & & & \\
\hline \multirow[t]{2}{*}{ 26. I believe I occupy a special position in society. } & $\mathrm{BS}$ & 41.03 & 778.0 & -.20 & .84 \\
\hline & $\mathrm{CV}$ & 40.02 & & & \\
\hline \multirow[t]{2}{*}{ 27. When on duty, I feel that I have a special kind of authority. } & BS & 42.43 & 724 & -.74 & .46 \\
\hline & $\mathrm{CV}$ & 38.75 & & & \\
\hline \multirow[t]{2}{*}{ 28. The powers I have as an officer are morally right. } & BS & 40.66 & 792 & -.06 & .95 \\
\hline & $\mathrm{CV}$ & 40.36 & & & \\
\hline
\end{tabular}

BS = Birmingham South (experimental site) $\mathrm{CV}=$ Coventry (control

\footnotetext{
${ }^{1}$ In retrospect, we are cognizant that participants may have been confused about the question (are they 'against hotspots policing, or against the temporal aspect of the patrols?). Our intention was to ask police officers to reflect on the utility of [hot spot patrols + within the confinements of 15 minutes], as the substantive definition of "hot spots policing" (e.g., Telep, Mitchell, \& Weisburd, 2012).
} 